http://dx.doi.org/10.18778/1508-1117.23.09

Stanisław Mordwa

\title{
SUBIEKTYWNE POCZUCIE ZAGROŻENIA A ZACHOWANIA OBRONNE MIESZKAŃCÓW LODZI
}

Zarys treści: Zakłada się, że zachowania obronne mieszkańców w przestrzeni miasta są reakcją na realne bądź percypowane zagrożenia tam występujące. Zagrożenia te mogą mieć charakter społeczny, materialny i socjalny, zdrowotny, związany ze stanem środowiska czy wreszcie charakter związany z bezpieczeństwem międzynarodowym. Zasadniczym celem artykułu jest opis i analiza różnych aspektów zachowań obronnych mieszkańców, które powstały wskutek różnorodnych i zróżnicowanych przestrzennie zagrożeń występujących w Łodzi.

Słowa kluczowe: zachowania obronne, poczucie bezpieczeństwa, zagrożenia społeczno-przestrzenne, Łódź.

\section{Wprowadzenie}

W koncepcji postawy Stevena J. Brecklera (1984), która jest bardzo często wykorzystywana w badaniach dotyczących poczucia bezpieczeństwa mieszkańców, można wyróżnić trzy komponenty: poznawczy (kognitywny, racjonalny), emocjonalny (afektywny) i behawioralny (konatywny). Pierwszy dotyczy subiektywnej oceny ryzyka wiktymizacji, drugi poziomu zagrożeń w środowisku zamieszkania. Komponent behawioralny natomiast opisuje zachowania jednostek w środowisku zamieszkania związane z reakcją na zagrożenia środowiskowe i społeczne w postaci podejmowanych działań obronnych (aktywnych i pasywnych). Zachowania obronne polegają na stosowaniu różnych zabezpieczeń i środków obniżających ryzyko stania się ofiarą różnych zagrożeń.

Termin ,,bezpieczeństwo” pochodzi od łacińskiego securitas (a dokładnie od sine - bez i cura - strach, obawa, zmartwienie) oznaczającego ,brak kłopotów, spokój". Bezpieczeństwo można zdefiniować jako uniezależnienie od jakiegokolwiek zagrożenia realnego lub wyobrażanego, a dotyczącego sytuacji aktualnej, albo mogącej wystąpić w przyszłości (rys. 1). Taki komfort osiągają jednak tylko nieliczni, dla pozostałych stanowi on bowiem sytuację niezwykle rzadką. 
Obraz społecznej realności dzisiejszego świata skłonił Z. Baumana (2004) do postawienia diagnozy, że w konsekwencji zmian jakie zachodzą we współczesnym świecie, coraz więcej ludzi przechodzi z bezpiecznego i szczęśliwego grona osób mogących pozwolić sobie na satysfakcjonujące życie do świata egzystencjalnego lęku oraz niepokoju o własny byt.

Pojęcie bezpieczeństwa można rozpatrywać na wielu poziomach: indywidualnym (osobistym), lokalnym społecznym, krajowym i międzynarodowym. Bezpieczeństwo osobiste to: uodpornienie na sytuacje związane z zagrożeniem życia, zdrowia, rodziny i bliskich, dobrobytu czy zachowaniem stanu środowiska zamieszkania. Bezpieczeństwo społeczne to działanie różnych instytucji funkcjonujących w środowisku społeczno-kulturowym, które zapobiegają ekonomicznej i społecznej nędzy, mogącej być efektem redukcji zarobków, chorobą, macierzyństwem, dyskryminacją zatrudnienia, bezrobociem, niepełnosprawnością, podeszłym wiekiem i śmiercią. Bezpieczeństwo narodowe rozumiane jest głównie jako stan obronności osoby, społeczeństwa i państwa przed niebezpieczeństwami tak zewnętrznymi, jak i wewnętrznymi. Bezpieczeństwo międzynarodowe to natomiast stan stosunków międzynarodowych, który ogranicza naruszenie pokoju i wytworzenie stanu realnego zagrożenia rozwoju ludzkości. Ze względu na dziedzinę jakiej dotyczy, bezpieczeństwo może odnosić się do zagrożeń ekologicznych, środowiskowych (ludzie od dawna są narażeni na takie zagrożenia, jak powodzie, wichury, huragany, pożary lasów, osuwiska, trzęsienia ziemi, upadki meteorytów czy wybuchy wulkanów), ekonomicznych, surowcowych (zwłaszcza energetycznych), fizycznych, informatycznych, kulturowych, militarnych, politycznych, socjalnych i społecznych (w tym różne patologie).

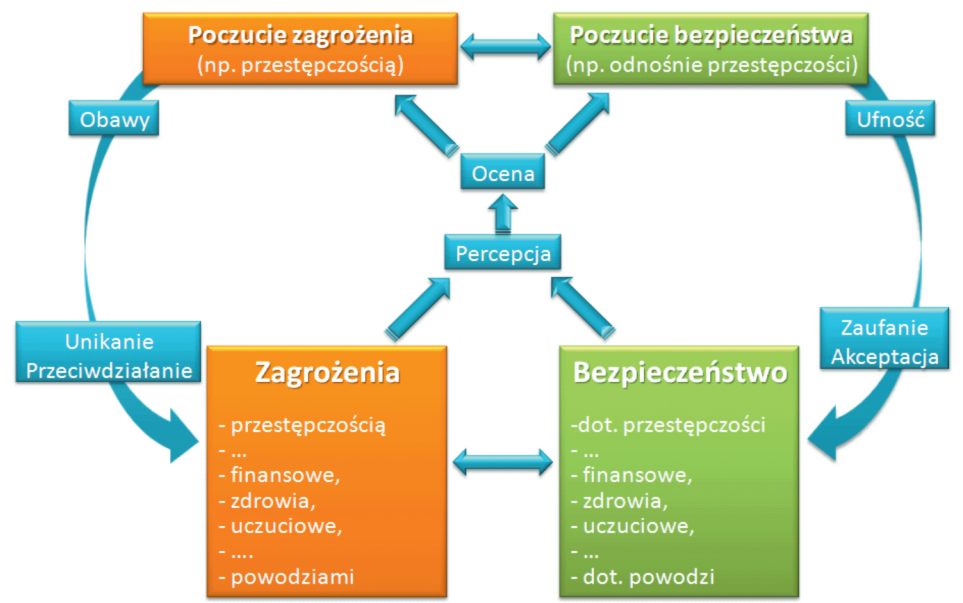

Rys. 1. Poczucie bezpieczeństwa/zagrożenia jako reakcja na występujące warunki bezpieczeństwa/zagrożenia

Źródło: opracowanie własne 
Główny obszar występowania omawianych zagrożeń to współczesne miasto (Jasiński 2009), bardzo zróżnicowane społeczno-przestrzennie. Jak pisał A. Wallis: „Miasto jest narzędziem nierówności społecznej. Powstaje pod wpływem tych nierówności, ułatwia je i potęguje" (Wallis 1971, s. 23). Fenomen ten został zauważony już dawno. Przedstawiciele wielu dyscyplin naukowych, którzy zajmowali się miastem jako podmiotem badań wnieśli swój wkład teoretyczny w analizę m.in. problemów społecznych w przestrzeni miast. Należą do nich geografowie, socjologowie, urbaniści, architekci, psychologowie i inni. Do najważniejszych osiągnięć teoretycznych należy zaliczyć teorię dezorganizacji społecznej, koncepcję obszarów społecznych miasta (E. Shewky, W. Bell, S. Williams), model ponowoczesnej struktury miasta (M. Dear), koncepcję miasta dualnego (M. Castells) i miasta globalnego (S. Sassen) czy opisywane w literaturze kryminologicznej: teorię „wybitych szyb” (G. Kelling i J. Wilson), wzorzec przestępczości (P. i P. Brantingham), perspektywę działań rutynowych (M. Felson, L. Cohen). Opierając się na wynikach badań polskich naukowców (głównie socjologów i geografów) można sformułować kilka prawidłowości związanych z występowaniem problemów społecznych w polskich miastach. I tak do obszarów, gdzie występują największe zagrożenia społeczne w miastach należy zaliczyć przede wszystkim centra miast oraz osiedla wielkoblokowe, starsze osiedla blokowe, obszary podmiejskie (położone wzdłuż mało ruchliwych ulic o peryferyjnym położeniu oraz wzdłuż tras wylotowych), dawne osiedla przyzakładowe. Ponadto obszary problemowe w centrach polskich miast utrzymują się od okresu międzywojennego. Tzw. enklawy biedy charakteryzują się takimi zjawiskami, jak: dekapitalizacja przestrzeni mieszkaniowej, bezrobocie, uzależnienie mieszkańców od pomocy społecznej, nasilenie zachowań patologicznych: przestępczość, alkoholizm, zjawisko rozbitej/niepełnej rodziny, przemoc w rodzinie (Czekaj 1991; Grotowska-Leder 2001; Węcławowicz 2001; Prawelska-Skrzypek, Porębski 2003; Kotus 2005; Zborowski 2010; Wolaniuk 2012; Mordwa 2014; Weltrowska, Kisiała 2014). Bardzo inspirujący jest przedstawiony w artykule A. Zborowskiego (2010) cykl degradacji śródmieścia. Opisuje on wzajemny układ różnorodnych niekorzystnych zjawisk prowadzących do przestrzennej i społecznej degradacji centralnych obszarów polskich miast - co zgodnie z teorią wybitych szyb prowadzi do eskalacji percypowanego zagrożenia i może spowodować wyprowadzenie się miejscowych elit i dalszego pogłębiania się poziomu faktycznych zagrożeń. Według autora omawianego cyklu procesy degradacji polskich miast sięgają okresu powojennego, kiedy to dokonano zanegowania prawa własności wielu nieruchomości i dokonano komunalizacji lub nacjonalizacji dotychczas prywatnego budownictwa czynszowego. Brak zainteresowania starą substancją mieszkaniową ze strony „nowych” właścicieli (obszary przemysłowe i wielkogabarytowe osiedla blokowe były wówczas priorytetami) oraz brak środków na remonty doprowadziły do znacznej jej degradacji materialnej (substancji 
budowlanej i infrastruktury technicznej). Cykl degradacji śródmieść, oprócz przemian dokonujących się w warstwach urbanistyczno- infrastrukturalnej oraz prawno-własnościowej i administracyjnej, rozegrał się także na płaszczyznach ekonomicznej i społecznej. Wymiar ekonomiczny na opisywanym obszarze miasta w okresie transformacji charakteryzował się niskim poziomem przedsiębiorczości, któremu towarzyszył upadek uprzednio istniejących tutaj usług i handlu. Jednak to w warstwie społecznej śródmieścia doznały najwięcej różnorodnych przemian i procesów. Po II wojnie światowej obszary te zostały intensywnie zasiedlone, przede wszystkim ludnością o niskim kapitale społecznym, w tym także bardzo słabo wykształconą ludnością ze wsi. Spowodowało to ogólny wzrost gęstości zaludnienia, która znalazła swój wymiar także w postaci przeludnienia mieszkań. Od lat 70. XX wieku lepiej sytuowani i wykształceni młodzi mieszkańcy śródmieść zaczęli emigrować, początkowo do osiedli blokowych, a później na przedmieścia. Spowodowało to dodatkowe uwypuklenie skali problemów społecznych centrów miast. Starzenie się społeczeństw dużych miast, co jest obecnie odnotowywane, prowadzi do depopulacji głównie tych obszarów, które charakteryzowały się najniższym poziomem i jakością życia, czyli śródmieść. Dodatkowo etykietowanie i stygmatyzacja tych obszarów spowodowane postępującym tutaj skumulowaniem zjawisk patologicznych nie pozwala na widzenie ich przyszłości w pozytywnych barwach. Najwięcej problemów społeczno-przestrzennych, według autora cyklu degradacji śródmieść, stwarzają takie zjawiska patologiczne, jak bezrobocie, niepełne rodziny, ubóstwo i przestępczość.

Poczucie bezpieczeństwa to jedna z podstawowych potrzeb człowieka, stanowiąca zasadniczy warunek jego zdrowia psychicznego, konieczna do normalnego funkcjonowania ludzi i społeczeństw (Sillamy 1989). Zagadnienia związane $\mathrm{z}$ bezpieczeństwem człowieka $\mathrm{w}$ różnych definicjach i klasyfikacjach potrzeb, przeważnie wysuwane są na pierwszy plan. Tak jest w hierarchicznej teorii potrzeb A. Maslowa, teorii kultury B. Malinowskiego czy teoriach C. Alderfera (teoria ERG) i H. Murray'a (bezpieczeństwo rozumiane jako potrzeba unikania urazów fizycznych i psychicznych).

Zachowania obronne mieszkańców Łodzi kilkukrotnie badał już S. Mordwa, aczkolwiek tylko te zachowania, które były reakcją na zagrożenie przestępczością (por.: Mordwa 2010, 2011, 2012, 2013). W publikacjach tych zaobserwowano kilka prawidłowości. Okazało się np., że różnice w zachowaniach obronnych między mieszkańcami poszczególnych osiedli miasta są bardzo istotne. Wyróżnili się mieszkańcy Julianowa (unikanie publicznych środków komunikacji, schodzenie z drogi określonym grupom) i Nowego Miasta (najczęściej stosowanym środkiem pasywnym było staranie się, aby dzieci nie wychodziły wieczorem). Aktywne zachowania obronne były stosowane rzadziej. Dokładnie rzecz ujmując popularne wśród łodzian były tylko dwa zachowania tego typu: dodatkowe zabezpieczanie mieszkań w zamki, kraty, wzmocnienia drzwi itp. (najczęściej na 
Julianowie) oraz montaż alarmu $w$ samochodzie. Okazało się, że mimo wysokiego poczucia zagrożenia przestępstwami prawie $1 / 4$ respondentów nie podejmowała żadnych działań ochronnych (osobami, które nie stosują żadnych środków zabezpieczeń były głównie osoby młode, w równym stopniu kobiety co mężczyźni). Stosowanie większej liczby zabezpieczeń częściej deklarowały kobiety i osoby starsze, ale zdecydowanie częściej wybierały one zachowania pasywne, polegające na unikaniu niechcianych sytuacji zagrożenia. Wszystkie kobiety często stosowały omijanie określonych miejsc, natomiast panie oraz osoby powyżej 51. roku życia stosowały głównie schodzenie z drogi określonym grupom osób. Stosowanie aktywnych zachowań obronnych skorelowane było z płcią i wiekiem. Są one bardziej charakterystyczne dla mężczyzn niż dla kobiet. Panowie częściej deklarowali, że: brali udziat w kursach samoobrony, nosza broń albo nóż, montuja alarmy $w$ domu i/lub $w$ samochodzie. Więcej osób w średnim wieku stosuje tego typu zabezpieczenia, najrzadziej robią to zaś osoby najmłodsze. Co ciekawe, bezpośrednie doświadczenie wiktymizacyjne w przypadku żadnego zachowania obronnego nie okazało się istotne. Oznacza to, że stosowanie czy to pasywnych, czy aktywnych form ochrony generalnie nie ma związku z tym, czy ktoś był już poszkodowany w jakimś zdarzeniu przestępczym.

Celem tego opracowania jest weryfikacja hipotezy, zgodnie z którą w przestrzeni Łodzi mamy do czynienia ze zróżnicowaniem postaw związanych z zachowaniami obronnymi mieszkańców miasta, które są reakcją na dysproporcje przestrzenne występujących w przestrzeni Łodzi różnorodnych zagrożeń i patologii społecznych.

\section{Charakterystyka projektu badawczego, obszary badań}

\subsection{Charakterystyka projektu badawczego}

Podstawowym źródłem informacji wykorzystanym w tym opracowaniu były wywiady kwestionariuszowe. Wywiady te na obszarach Centrum-Północ, Centrum-Południe, Karolewa, Radiostacji i Dołów przeprowadzono w okresie październiklistopad 2013 roku (były one niejako uzupełnieniem badań przeprowadzonych na tych samych obszarach w latach 2011-2012 w ramach projektu Dysproporcje spoteczne i gospodarcze w przestrzeni Łodzi. Czynniki, mechanizmy, skutki-którego wyniki zostały opublikowane w: Suliborski, Wójcik 2014). W przypadku osiedli Centrum-Północ, Centrum-Południe i Karolew przebadano po 200 przypadkowo spotkanych dorosłych respondentów, dobranych w sposób celowo-losowy, według ich zamieszkania. W ten sam sposób uzyskano po 150 opinii spośród mieszkańców Radiostacji i Dołów. Krótki kwestionariusz wywiadu obejmował problematykę dotyczącą percepcji zagrożeń i poczucia bezpieczeństwa, a dalej przedstawione wyniki stanowią część danych, zogniskowaną na tematyce tego opracowania. 
Wśród badanych było 538 kobiet i 362 mężczyzn; wyraźnie większy udział kobiet zanotowano w południowej części Centrum (62,4\%), a najniższy w Radiostacji (54,9\%). Mediana wieku wyniosła 38 lat (przeciętnie najmłodsi byli respondenci z Centrum-Północy [35] i Centrum-Południa [36], a najstarsi z Karolewa [44]). Poszczególne grupy wiekowe były mniej więcej tak samo liczne. Niewiele więcej osób było w wieku 18-29 lat (28,7\%) oraz osób najstarszych (pow. 60 lat) - 25,4\%. Ponieważ struktura płci i wieku osób, które wzięły udział w badaniu różniła się od analogicznych struktur mieszkańców badanych osiedli, postanowiono dokonać ważenia uzyskanych wyników (w oparciu o odpowiednie struktury mieszkańców). Celem ważenia było zniwelowanie nadreprezentacji kobiet oraz dwóch grup wiekowych w zrealizowanej w trakcie badań terenowych próbie.

$\mathrm{W}$ trakcie tych badań ponownie okazało się, że ankietowani byli osobami nieco lepiej wykształconymi niż przeciętni łodzianie. Wynika to ze znanej w badaniach społecznych wyższej skłonności lepiej wykształconych osób i kobiet do brania udziału w tego typu badaniach. W prezentowanych badaniach $35,6 \%$ respondentów zadeklarowało wykształcenie wyższe i niepełne wyższe, $47,1 \%$ wykształcenie średnie, a tylko 17,3\% wykształcenie podstawowe lub zawodowe.

\subsection{Obszary badań}

Badania zostały przeprowadzone w pięciu obszarach Łodzi pokrywających się z czterema obszarami SIM (Systemu Informacji Miejskiej): Centrum (na potrzeby badań podzielone na część północną i południową), Karolew, Radiostacja i Doły. W wyborze obszarów kierowano się odmiennością ich typów zabudowy mieszkaniowej (rys. 2) i pełnionych funkcji oraz charakterystyką demograficzną mieszkańców. Obszar SIM Centrum obejmuje najbardziej prestiżowe tereny i lokalizacje w skali całego miasta, ale także sąsiadujące z nimi kwartały koncentracji biedy, ubóstwa i innych patologii społecznych (Grotowska-Leder 2001; Warzywoda-Kruszyńska 2001; Mordwa 2014). Przeważa na tym obszarze zabudowa śródmiejska o bardzo zróżnicowanym standardzie mieszkań: od w pełni wyposażonych, luksusowych lokali, po budynki substandardowe (Dzieciuchowicz 2011). Centrum, ze względu na znaczne rozmiary, podzielono na dwa obszary badań: Centrum-Północ i Centrum-Południe wzdłuż al. A. Mickiewicza i al. J. Piłsudskiego. Obszary te mają również różny charakter. Część północna to zwarta zabudowa XIX-wiecznych kamienic (zawierających funkcje mieszkalno-usługową), północny fragment ul. Piotrkowskiej pełni funkcję deptaka (o ograniczonym ruchu pojazdów), a różnorodne działania w tym miejscu mają przywrócić tej ulicy dawną świetność jako wizytówki i salonu miasta. Centrum-Północ ma powierzchnię 198 ha, był zamieszkiwany przez 32 tys. mieszkańców i miał największą gęstość zaludnienia - 16,2 tys. osób na km². Obszar ten wyróżniał się cechami demograficznymi mieszkańców, gdyż kobiety stanowiły tutaj tylko 54\% osób, a wskaźnik 
feminizacji był najniższy - 118 kobiet na 100. W skali ogólnołódzkiej jest to obszar młody demograficznie: największy był tu udział mieszkańców w wieku do 19 lat $(20 \%)$ oraz najmniej było mieszkańców w wieku poprodukcyjnym (tylko $13 \%$ ). Natomiast południowy fragment ul. Piotrkowskiej pełni normalne funkcje komunikacyjne, a okoliczne obszary są $\mathrm{w}$ większym stopniu zdezorganizowane przestrzennie, przenikają się tutaj tereny mieszkaniowe z obszarami składowymi, poprzemysłowymi czy ugorami miejskimi. Na tym obszarze o powierzchni 138 ha mieszkało ok. 12,5 tys. osób ( 9 tys. osób na km²). Mniej było tutaj osób należących do najmłodszej grupy wiekowej (16\%), a więcej było osób najstarszych (19\%). Struktura płci - 55\% mieszkańców to kobiety - zbliżona była do wartości przeciętnej dla całego miasta.

Karolew zajmuje powierzchnię 153 ha i dominuje tu funkcja mieszkaniowa. Charakterystyczne dla tego obszaru jest duże zagęszczenie podobnych do siebie budynków wznoszonych metodą wielkopłytową. Jest to zabudowa blokowa pochodząca $\mathrm{z}$ drugiej połowy lat 60 ., silnie zróżnicowana pod względem liczby kondygnacji i liczby lokali mieszkalnych wyposażonych w podstawowe instalacje, ale przeważnie o małej powierzchni użytkowej. Wzdłuż ul. J. Kozietulskiego, w zachodniej części osiedla, położony jest niewielki teren zabudowy mieszkaniowej jednorodzinnej (3,6 ha). Karolew zamieszkiwało prawie 13 tys. mieszkańców, gęstość zaludnienia wynosiła ponad 8,3 tys. osób na km². W odróżnieniu od Centrum to obszar silniej sfeminizowany (kobiety stanowiły 57\% mieszkańców). Znaczny był udział ludności w wieku poprodukcyjnym (34\%), jednak mieszkało tutaj bardzo mało dzieci i młodzieży (ich udział w populacji wynosił tylko 13\%).

Obszar Radiostacji znajduje się w najbardziej wysuniętej na wschód części Śródmieścia i zajmuje powierzchnię 166 ha. Na północy tego obszaru dominują tereny o przewadze zabudowy wielorodzinnej, w części południowej znajdują się tereny o przewadze zabudowy mieszkaniowej jednorodzinnej, Pomiędzy tymi terenami mieszkaniowymi znajduje się strefa $\mathrm{z}$ dominującą funkcją usług o charakterze metropolitalnym $\mathrm{z}$ wtrąceniami zabudowy czynszowej i modernistycznymi willami. W skali całego miasta warunki mieszkaniowe na obszarze Radiostacji wyróżniają się bardzo pozytywnie (Dzieciuchowicz 2011). Zwłaszcza południowa część należy do najbardziej preferowanych przez łodzian miejsc do zamieszkania (Mordwa 2003). W 2009 roku obszar ten zamieszkany był przez niecałe 6,5 tys. mieszkańców, co dawało ponad 3,9 tys. osób na km². Wyróżniał się najwyższym odsetkiem kobiet - 58\% (współczynnik feminizacji wynosił tutaj aż 137) oraz najwyższym udziałem osób w wieku poprodukcyjnym - 34\%. Jednocześnie mieszkało tutaj mało osób w wieku do 19 lat (13\%).

Od północy z Radiostacją sąsiadują Doły, które mają powierzchnię 210 ha. Mieszkańcy Łodzi kojarzą ten obszar z kompleksem cmentarzy różnych wyznań, a stanowiącym aż $21 \%$ powierzchni osiedla. Na tym osiedlu znajdują się również tereny: usług o charakterze metropolitalnym, zabudowy mieszkaniowej - jedno- 
rodzinnej, zabudowy mieszkaniowej wielorodzinnej, o funkcjach przemysłowo-usługowych. Obszar ten robi ogólne wrażenie nieuporządkowanego, bez wyrazu (poza funkcją cmentarną), niejednorodny pod względem pełnionych funkcji, o chaotycznym ich rozmieszczeniu. W przeprowadzonych badaniach Doły były najsłabiej zaludnionym obszarem spośród uwzględnionych - 4,3 tys. mieszkańców (ponad 2 tys. osób na $\mathrm{km}^{2}$ ). Społeczność Dołów była wyraźnie sfeminizowana (131 kobiet przypadało na 100 mężczyzn). W strukturze wieku wyraźnie zaznaczał się znaczny udział osób w wieku poprodukcyjnym (32\%), przy jednocześnie bardzo niskim udziale dzieci i młodzieży do lat 19 (14\%).

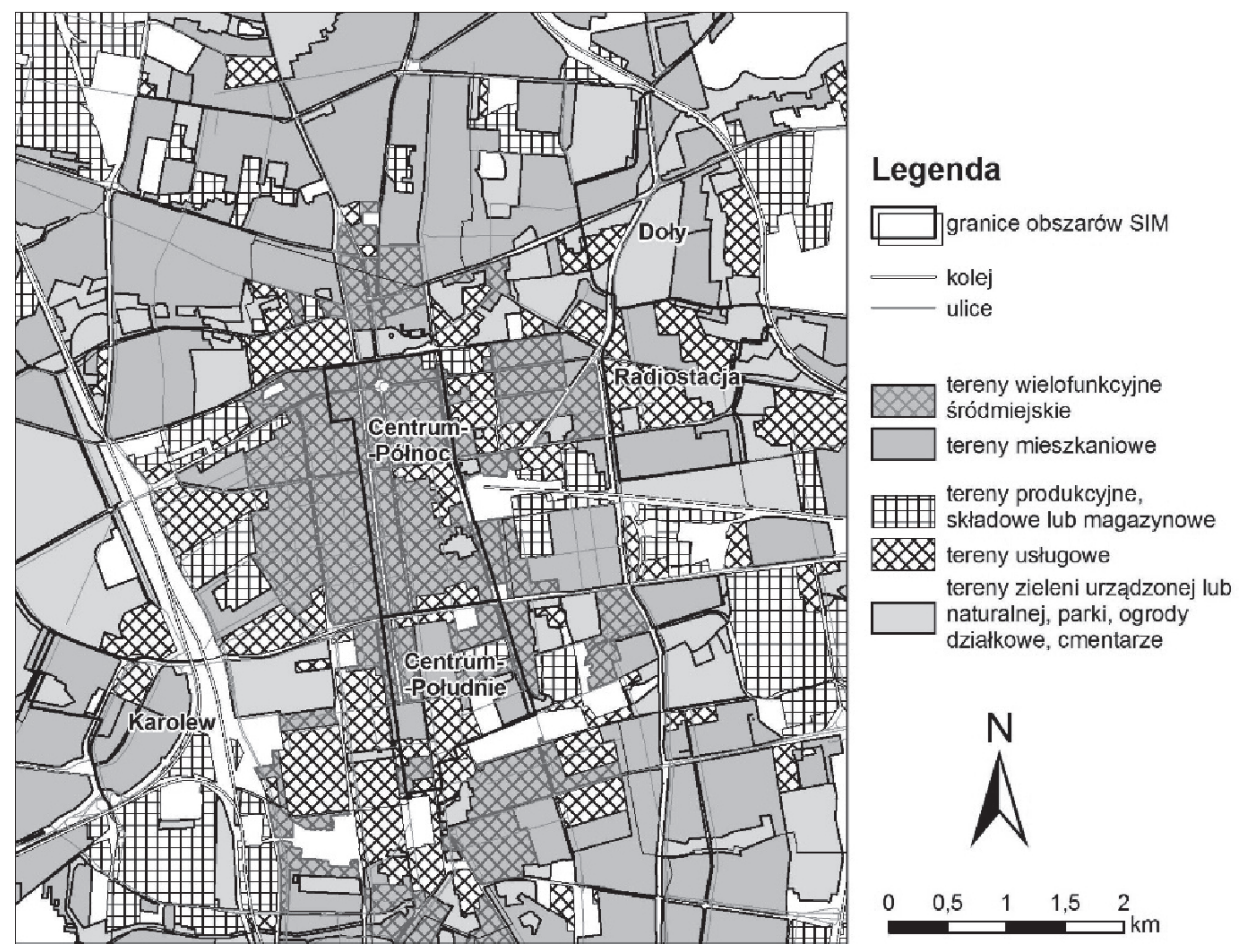

Rys. 2. Obszary badań

Źródło: opracowanie własne

W oparciu o powyższe charakterystyki stwierdzić można, że Karolew, Doły i Radiostacja (położone w bliskim sąsiedztwie Centrum) to obszary o bardzo podobnych strukturach wieku i płci mieszkańców, ale jednocześnie bardzo różniące się zagospodarowaniem przestrzeni.

W badaniach przeprowadzonych w 2011 i 2012 roku na tych samych obszarach oceniono wagę problemów tam występujących (Mordwa 2014). Poszczególne problemy uporządkowano nadając im hierarchię, w efekcie czego okazało się, że najważniejsze problemy na pięciu obszarach badań stanowiły (tab. 1): bezrobo- 
cie (poważny i bardzo poważny problem dla 50\% respondentów), za mało policji i straży miejskiej na ulicach (50\%), pijacy na ulicy (46\%), grupy watęsajacej się młodzieży (49\%) oraz wandalizm (48\%). Ponadto przewagę opinii o dokuczliwości danego problemu stwierdzono jeszcze w przypadku: biedy, brudu i śmieci na ulicach $i$ w parkach, dostepu do pomocy społecznej, zrujnowanych/zaniedbanych budynków oraz napisów/graffiti na murach. Jako nieistotne lub mało istotne ogół respondentów określał w swojej okolicy m.in. takie problemy, jak: przestępczość, przemoc $w$ rodzinie, napastowanie kobiet $i$ dziewczat, narkomani $i$ handlarze narkotyków, złe oświetlenie ulic.

Najważniejszą zmienną decydującą w ocenie problemów było miejsce zamieszkania respondentów, a ich dotkliwość była bardzo różnie oceniana przez osoby z poszczególnych obszarów badawczych. Analiza poszczególnych rodzajów problemów doprowadziła do wniosku, że przede wszystkim obszar Centrum-Północ jest szczególnie dotknięty wysokim natężeniem różnych problemów. Stwierdzono tutaj największą istotność aż 13 z 18 przedstawionych w kwestionariuszu problemów. Były to: zrujnowane/zaniedbane budynki, napisy/graffiti na murach, mało policji $i$ staży miejskiej na ulicach, grupy wałesającej się młodzieży, bezdomni $i$ żebracy, wandalizm, napastowanie kobiet i dziewczat, pijacy na ulicy, przemoc $w$ rodzinie, za duży hałas, narkomani i handlarze narkotyków, dostęp do pomocy społecznej, brud i śmieci na ulicach $i$ w parkach. Ponadto, w przypadku czterech problemów, obszar ten znalazł się na drugim miejscu wśród najbardziej zagrożonych. Tak złej ocenie poddane zostały: bezrobocie, przestępczość, złe oświetlenie ulic oraz możliwości spędzania wolnego czasu. Te same problemy przedstawione do oceny w południowej części Centrum rzadziej traktowane były jako ważne lub bardzo ważne - w ośmiu przypadkach ocena respondentów usytuowała ten obszar na drugim miejscu. Istotnymi problemami były: zrujnowane/zaniedbane budynki, grupy watęsającej się młodzieży, wandalizm, przemoc w rodzinie, za duży hałas, narkomani i handlarze narkotyków, dostęp do pomocy spolecznej, brud i śmieci na ulicach $i$ w parkach. Obszar ten wyraźnie odróżniał się od swojego sąsiada.

Doły były kolejnym najgorzej ocenianym przez swoich mieszkańców osiedlem. Tutaj najwięcej mieszkańców miało najbardziej krytyczny osąd w takich kwestiach, jak: bezrobocie, przestępczość, złe oświetlenie ulic, możliwości spędzania wolnego czasu. Ponadto aż pięć problemów z tego obszaru znalazło się na drugim miejscu pod względem ogólnej dokuczliwości. Natomiast w Radiostacji najmniejszy był udział respondentów uznających występujące na danym obszarze problemy za istotne. W porównaniu $\mathrm{z}$ osobami z innych obszarów miejscowi ankietowani najłagodniej ocenili natężenie aż 11 problemów. W pozostałych siedmiu przypadkach uczynili tak mieszkańcy Karolewa - chociaż oni akurat byli ponadto najbardziej ze wszystkich respondentów krytyczni w ocenie biedy (najczęściej uznawana za bardzo poważny problem na tym obszarze właśnie) i bezrobocia (drugie miejsce za mieszkańcami Dołów w ocenie powagi tego problemu). 
Hierarchia problemów występujących na badanych obszarach

\begin{tabular}{|c|c|c|c|c|c|}
\hline Ogółem & $\begin{array}{c}\text { Centrum- } \\
\text {-Północ }\end{array}$ & $\begin{array}{c}\text { Centrum- } \\
\text {-Południe }\end{array}$ & Doły & Karolew & Radiostacja \\
\hline bezrobocie & pijacy & brud & pijacy & bezrobocie & bezrobocie \\
\cline { 2 - 6 } & wandalizm & bezrobocie & bezrobocie & bieda & \\
\cline { 5 - 7 } pijacy & brud & wandalizm & & młodzież & bieda \\
\hline młodzież & zaniedbane & pijacy & oświetlenie & & młodzież \\
\hline wandalizm & młodzież & młodzież & pomoc & pomoc & pomoc \\
\hline
\end{tabular}

Uwaga: rozwinięcie terminów występujących w tabeli: 'mało policji' - mało policji i straży miejskiej na ulicach; 'pijacy' - pijacy na ulicy; 'młodzież' - grupy wałęsającej się młodzieży; 'brud' - brud i śmieci na ulicach i w parkach; 'zaniedbane' - zrujnowane/ zaniedbane budynki; 'oświetlenie' - złe oświetlenie ulic; 'pomoc' - dostęp do pomocy społecznej.

Źródło: S. Mordwa (2014).

W wyniku analizy pozyskanych w trakcie badań danych można stwierdzić, że respondenci różnili się w ocenie występowania poszczególnych problemów. Różnice dotyczyły nie tylko hierarchii ich ważności, ale także na wskazywaniu parokrotnie zupełnie innych problemów. Hierarchia pięciu najważniejszych specyficzna jest w poszczególnych badanych obszarach, jest także różna od hierarchii problemów otrzymanej na podstawie opinii ogółu respondentów (tab. 1). Na przykład, zupełnie inne problemy w opinii mieszkańców dotykają obszar Centrum-Północ, gdzie wskazywane są w większości problemy związane z charakterystykami higienicznymi i stanem technicznym zamieszkiwanego miejsca (wandalizm, brud, zaniedbane budynki) oraz problemy społeczne związane z obecnościa osób nietrzeźwych i wałęsajacej się młodzieży w przestrzeni publicznej. Południową część Centrum nękają wg jej mieszkańców najważniejsze problemy: brud i śmieci na ulicach $i$ w parkach oraz wandalizm. Dla mieszkańców Dołów ważnym jest zwrócenie uwagi na złe oświetlenie ulic. Respondenci z Karolewa i Radiostacji podnieśli natomiast rangę dwóch innych problemów dotyczących tych obszarów, a które związane są ogólnie z bieda oraz dostępem do uzyskania pomocy społecznej (Mordwa 2014).

\section{Emocjonalny komponent poczucia bezpieczeństwa - ocena poziomu zagrożeń}

Badania dotyczące poczucia bezpieczeństwa/zagrożenia mieszkańców wybranych osiedli w Łodzi stanowiły jeden z podstawowych celów realizowanego projektu. Uzyskane wyniki powstały na podstawie odpowiedzi na jedno z głównych 
pytań badawczych: jaki jest poziom poczucia bezpieczeństwa mieszkańców oraz poziom odczuwanego zagrożenia w poszczególnych częściach miasta?

Uogólnione obrazy poczucia zagrożenia w poszczególnych częściach miasta powstały na podstawie odpowiedzi na sześć pytań, co przedstawiono na rys. 3. Widoczna jest przede wszystkim różnica w ocenie własnego bezpieczeństwa w tych samych miejscach w ciągu dnia oraz po zmroku. Ta prawidłowość obowiązuje w każdej badanej społeczności osiedlowej. Przebywanie we własnym mieszkaniu lub domu, bloku lub okolicy własnego domu oraz na ulicach osiedlowych zawsze było odbierane jako bezpieczniejsze - na rys. 3a widoczne są wyższe odsetki osób deklarujących brak poczucia bezpieczeństwa w tych samych miejscach po zmroku. Różne są natomiast proporcje między liczbą deklarujących wysoki poziom zagrożenia $\mathrm{w}$ analizowanych miejscach $\mathrm{w}$ ciągu doby - największe stwierdzono w przypadku oceny bezpieczeństwa przez samotnego pieszego, najmniejsze natomiast dotyczyły poczucia bezpieczeństwa w domu.

Ogólnie można zauważyć, że w odczuciu respondentów najmniej bezpieczne są ulice wieczorem i w nocy. $42 \%$ badanych przyznało, że nie czuje się bezpiecznie o tej porze podczas spacerów ulicami swojego osiedla. Znacznie mniej badanych, $20 \%$ wszystkich respondentów, nie czuje się bezpiecznie po zmroku w swoim bloku (np. winda, klatka schodowa, piwnica) lub na swojej działce wokół własnego domu. Najbardziej bezpieczne jest własne mieszkanie lub dom (tylko 4\% osób nie czuje się tam bezpiecznie w ciągu dnia, a 11\% po zmroku). Wyraźnie także widać (rys. 3b-f), że ogólne prawidłowości oceny bezpieczeństwa $\mathrm{w}$ każdym $\mathrm{z}$ tych miejsc powielają się $\mathrm{w}$ nieco tylko różnych proporcjach dla populacji respondentów reprezentujących badane pięć osiedli. Widać także, że wszędzie poczucie bezpieczeństwa większe jest w ciągu dnia niż po zmroku.

Chociaż, jak stwierdzono, generalnie powyższe prawidłowości w ocenach bezpieczeństwa/zagrożenia powielają się w opiniach mieszkańców różnych obszarów miasta, to można zaobserwować także, że w niektórych z nich mieszkańcy odczuwają większy komfort bezpieczeństwa niż w innych. Okazało się, że miejsce zamieszkania respondentów istotnie różnicowało opinie wyrażone w odpowiedziach na wszystkie sześć pytań dotyczących oceny bezpieczeństwa (ocenę istotności badano za pomocą testu $\chi^{2}$, wszystkie wyniki były istotne na poziomie co najmniej $\mathrm{p}=0,01)$. Okazało się, że w obu częściach Centrum wyraźnie więcej osób nie czuje się bezpiecznie - szczególnie na ulicach i po zmroku. W przypadku respondentów z Centrum-Południe takie niepokoje wyraziło aż 47\% osób, a wśród ich sąsiadów z Centrum-Północy udział ten wyniósł 44\%. Natomiast Doły i Radiostację tamtejsi respondenci uznali generalnie za bezpieczne osiedla. Tylko około co trzecia osoba wyrażała swój brak poczucia bezpieczeństwa spacerując wieczorami i w nocy po ulicach tych osiedli. Pozostałe miejsca, niezależnie od pory dnia, wśród tutejszych mieszkańców rzadko wywoływały uczucie zagrożenia (każdorazowo było to poniżej 10\% badanych). Karolew natomiast uznany 
został przez swoich mieszkańców generalnie za bezpieczny, za wyjątkiem takich miejsc, jak klatka schodowa i inne miejsca w bloku oraz osiedlowe ulice (tutaj aż $45 \%$ osób wyrażało takie obawy) - za każdym razem chodziło o porę wieczorną i nocną.

a)

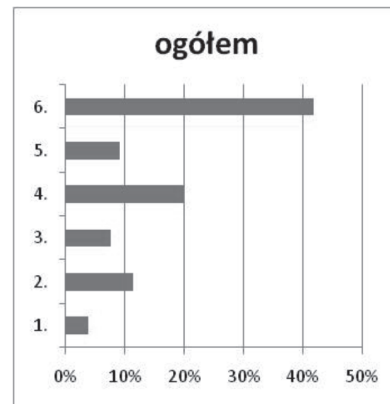

c)

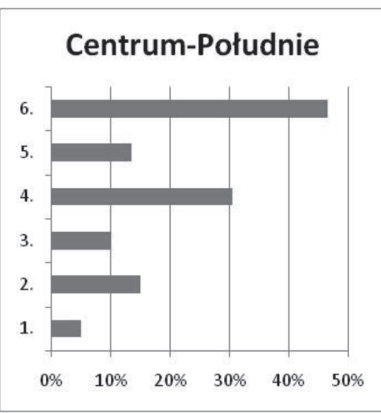

e)

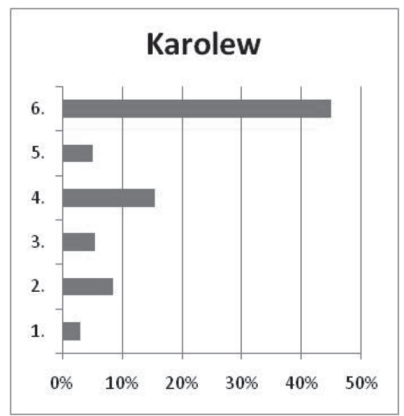

b)

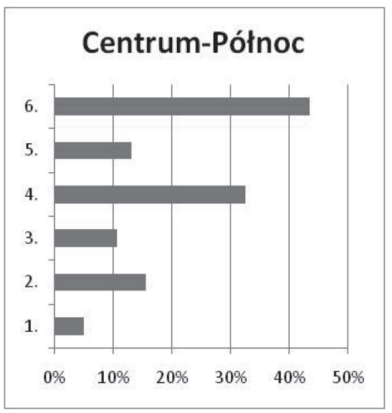

d)
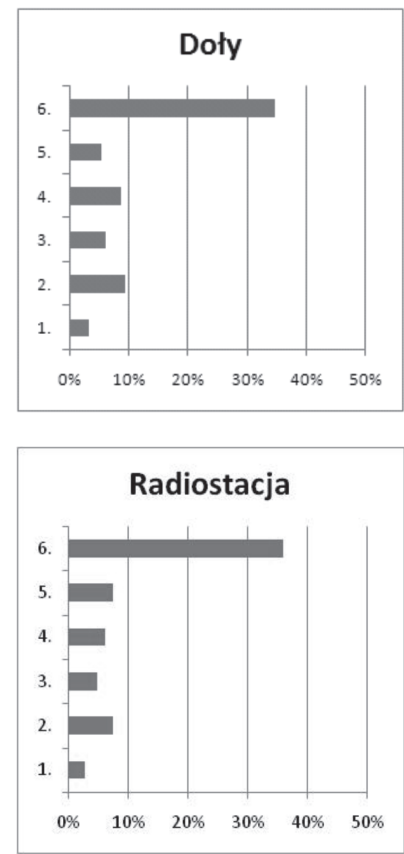

Rys. 3. Struktura odpowiedzi na pytanie: Czy czuje się Pan(i) bezpiecznie...? Uwaga 1. Suma odpowiedzi nie oraz raczej nie. Uwaga 2. Oznaczenie osi: 1. $\operatorname{sam}(a)$ $w$ domu/mieszkaniu w ciagu dnia; 2. $\operatorname{sam}(a) w$ domu/mieszkaniu $w$ nocy; 3. $\operatorname{sam}(a)$ $w$ bezpośrednim otoczeniu swojego domu lub $w$ różnych miejscach $w$ domu wielorodzinnym w ciagu dnia; 4. sam(a) w bezpośrednim otoczeniu swojego domu lub $w$ różnych miejscach $w$ domu wielorodzinnym w nocy; 5. sam(a) na osiedlowych ulicach w ciagu dnia; 6. sam(a) na osiedlowych ulicach w nocy

Źródło: opracowanie własne 
Na podstawie odpowiedzi na sześć opisanych powyżej pytań zbudowano skalę, w której dla każdej osoby określono jej subiektywne poczucia zagrożenia (tab. 2).

Tabela 2

Poczucie zagrożenia według płci, wieku i wykształcenia respondentów (w \%)

\begin{tabular}{|l|c|c|c|c|c|c|c|c|c|c|}
\hline $\begin{array}{c}\text { Subiek- } \\
\text {-tywne } \\
\text { poczucie } \\
\text { zagroże- } \\
\text { nia }\end{array}$ & $\begin{array}{c}\text { Ogó- } \\
\text { łem }\end{array}$ & $\begin{array}{c}\text { Ko- } \\
\text { bieta }\end{array}$ & $\begin{array}{c}\text { Męż- } \\
\text { czy- } \\
\text { zna }\end{array}$ & $18-29$ & $30-49$ & $50-59$ & $60+$ & $\begin{array}{c}\text { Płeć } \\
6 \text { Pod- } \\
\text { sta- } \\
\text { wowe, } \\
\text { zawo- } \\
\text { dowe }\end{array}$ & $\begin{array}{c}\text { Sred- } \\
\text { nie }\end{array}$ & $\begin{array}{c}\text { Wyż- } \\
\text { sze, } \\
\text { nie- } \\
\text { pełne } \\
\text { wyższe }\end{array}$ \\
\hline Brak & 24 & 13 & 41 & 30 & 25 & 21 & 19 & 22 & 22 & 35 \\
\hline Niskie & 19 & 19 & 19 & 11 & 22 & 18 & 24 & 16 & 23 & 15 \\
\hline Średnie & 34 & 41 & 24 & 42 & 24 & 38 & 32 & 34 & 35 & 31 \\
\hline Wysokie & 23 & 28 & 16 & 17 & 29 & 23 & 24 & 28 & 21 & 20 \\
\hline
\end{tabular}

Źródło: obliczenia własne.

Płeć, wiek i miejsce zamieszkania okazały się istotnymi zmiennymi charakteryzującymi respondentów, które wpływały na poziom subiektywnego poczucia zagrożenia ${ }^{2}$. Na podstawie prawie dwukrotnej przewagi kobiet nad mężczyznami wśród osób wyrażających najwyższe na skali poczucie zagrożenia (ponadto aż 69\% kobiet należy do grupy wyrażającej średnie lub wysokie wartości na skali poczucia zagrożenia, wobec tylko $40 \%$ mężczyzn), można twierdzić o ogólnie większym poczuciu zagrożenia wśród kobiet niż wśród mężczyzn. Dodać można, że aż $41 \%$ badanych mężczyzn wykazuje brak poczucia zagrożenia, a razem z grupą wykazujących niskie wartości poczucia zagrożenia, grupa takich mężczyzn wzrasta aż do $60 \%$ badanych osób tej płci.

Sprawdzono również, czy istnieje związek wieku respondentów z poziomem poczucia zagrożenia. Dokonane obserwacje nie są jednak tak jednoznaczne jak

${ }^{1} \mathrm{~W}$ tym celu zastosowano procedurę zaproponowaną przez J. Jerschinę z zespołem (2012). Otrzymana skala jest sumą wartości przyporządkowanych poszczególnym odpowiedziom, gdzie odpowiedzi tak przypisano wartość 1, raczej tak - wartość 2, raczej nie - wartość 3, nie - wartość 4. Następnie w zależności od wartości skali (sumy uzyskanych wyników) podzielono badane osoby na cztery grupy, charakteryzujące się niskim, średnim bądź wysokim poczuciem zagrożenia lub jego brakiem (granice punktowe między grupami ustalono tak, aby były one miej więcej równe liczebnie). Rzetelność opisanej skali sprawdzono przy pomocy współczynnika $\alpha$-Cronbacha, który w tym przypadku przyjął satysfakcjonującą wartość 0,68 .

${ }^{2}$ Wpływ wykształcenia okazał się nieistotny statystycznie, w przypadku pozostałych zmiennych testy $\chi^{2}$ były istotne na poziomie co najmniej $\mathrm{p}=0,05$. 
w przypadku płci. Wśród osób charakteryzujących się brakiem poczucia zagrożenia zauważalna jest jeszcze pewna tendencja: najmłodsi, zgodnie z oczekiwaniami, najczęściej reprezentują brak poczucia zagrożenia, a im respondenci są starsi, to tym mniej jest wśród nich osób deklarujących brak zagrożeń. W przypadku pozostałych trzech grup o niskim, średnim i wysokim poczuciu zagrożenia takich liniowych zależności już nie można wskazać. Także wśród czterech grup wiekowych nie można wskazać jednoznaczności. Na przykład, w najmłodszej badanej grupie wiekowej 18-29 lat, największa - aż 44\% jest grupa, która wyraziła średni poziom poczucia zagrożenia, łącznie z grupą charakteryzującą się wysokim poczuciem zagrożenia jest takich osób aż 59\%. Ponadto wśród osób najstarszych wcale nie dominują osoby o wysokim poziomie zagrożeń, ale osoby o średnim poczuciu zagrożenia, a największą grupą charakteryzującą się wysokim poziomem zagrożenia są osoby w wieku 30-49 lat (a więc z drugiej najmłodszej grupy). W przypadku grupy 30-49 lat można się tylko domyślać, że znaczny wpływ na ich poczucie bezpieczeństwa ma fakt, że osoby te posiadają małe dzieci. Znana jest w literaturze prawidłowość, że często bardziej niż o swoje bezpieczeństwo, obawiamy się o bezpieczeństwo naszych bliskich - a szczególnie dzieci. Nie można zatem stwierdzić na podstawie niniejszych analiz, że poczucie zagrożenia rośnie wraz z wiekiem - relacja ta jest bardziej skomplikowana.

Najwięcej osób charakteryzujących się wysokim poczuciem zagrożenia zamieszkiwało osiedla Centrum-Południe i Centrum-Północ (po ok. 28\% badanych), najmniej natomiast Radiostację (22\%) i Doły (20\%). Zachowana została zatem hierarchia osiedli w zakresie poziomu odczuwanych zagrożeń opisana przy okazji analizy odpowiedzi respondentów na pytanie, czy czują się oni bezpiecznie.

Wyniki dotyczące oceny poziomu zagrożeń, otrzymane przy pomocy analizy odpowiedzi uzyskanych na zadane sześć prostych pytań (i przekształconych na skalę subiektywnego poczucia zagrożenia), wyraźnie korespondują z poziomem natężenia różnych problemów społeczno-przestrzennych percypowanych przez mieszkańców badanych obszarów. Opisany najwyższy poziom natężenia problemów społecznych i przestrzennych w obu częściach Centrum niewątpliwie można połączyć ze znacznymi obawami mieszkańców o swoje bezpieczeństwo (szczególnie w porze nocnej) i znacznym udziałem tych osób wśród wyrażających wysokie poczucie zagrożenia. Natomiast w opinii mieszkańców Radiostacji na ich osiedlu natężenie problemów społecznych nie było bardzo istotne, co można wiązać z niskim poziomem zagrożenia odczuwanym w mieszkaniu/domu, bloku/okolicy domu i na ulicy. Niska istotność tutejszych problemów o charakterze społeczno-przestrzennym przekłada się tutaj na niskie subiektywne poczucie zagrożenia wśród mieszkańców. 


\section{Zachowania obronne podejmowane przez mieszkańców - strategie pasywne vs. aktywne}

Podstawowym celem prezentowanych badań było zidentyfikowanie zachowań obronnych, które podejmują mieszkańcy wybranych osiedli w Łodzi w celu ochrony przed potencjalnym zagrożeniem. W opracowaniach wielu autorów, tego rodzaju zachowania analizowane są w podziale na dwa typy strategii - pasywnych i aktywnych. Strategie pasywne związane są z zachowaniami polegającymi na unikaniu sytuacji uznawanych za niebezpieczne, czyli na omijaniu pewnych miejsc, okoliczności i grup ludzi. W związku z tym badane osoby zostały zapytane o to, czy unikają: komunikacji publicznej wieczorem $i$ w nocy, miejsc nieoświetlonych po zmroku, podejrzanie wygladajacych grup ludzi oraz czy unikaja samotnego wychodzenia z domu po zmroku. Strategie aktywne natomiast polegają na podejmowaniu czynnych działań zmierzających do ochrony przed spodziewanym zagrożeniem. Respondenci odnosili się do pytań związanych z dodatkowym zabezpieczeniem domu/mieszkania przed włamaniem (np. zamek, alarm), zabieraniem ze sobą przedmiotów służących do obrony, wychodzeniem z domu po zmroku w towarzystwie innej osoby lub psa, oraz związanych z udziałem osoby ankietowanej w kursie samoobrony. W przypadku obu strategii utworzone zostały skale pomiarowe, które pozwoliły na późniejsze określenie poziomu wykorzystania określonych strategii ${ }^{3}$. Jak się okazało przeciętnie mieszkańcy badanych osiedli wykazywali 2,3 zachowań pasywnych, przy tylko 0,9 zachowania aktywnego.

Podczas opracowywania wyników odpowiedzi okazało się, że niektóre rodzaje pasywnej i aktywnej obrony były stosowane bardzo często (unikanie miejsc nieoświetlonych po zmroku, unikanie podejrzanie wygladajacych grup ludzi, instalowanie dodatkowych zabezpieczeń domu/mieszkania przed włamaniem), inne były wykorzystywane bardzo rzadko (unikanie samotnego wychodzenia z domu po zmroku, udziat w kursie samoobrony). Najczęściej spotykanym zachowaniem pasywnym okazało się unikanie miejsc nieoświetlonych po zmroku, które wykazywało 73\% respondentów. Znacznie częściej takich miejsc unikają kobiety (84\%), niż mężczyźni. Ponadto okazało się, że zachowań takich istotnie nie różnicuje wiek ani wykształcenie. Opisywany rodzaj zachowań posiada natomiast swój wymiar przestrzenny. Ponadprzeciętnie tego typu strategię obronną stosowali mieszkańcy obu części Centrum oraz Radiostacji.

Drugim typowym pasywnym zachowaniem obronnym było unikanie podejrzanie wygladajacych grup ludzi, tak postępuje $69 \%$ osób, które poddały się badaniu. W przypadku tego zachowania ponownie istotnymi zmiennymi okazały się

\footnotetext{
${ }^{3} \mathrm{~W}$ przypadku obu strategii, każdej twierdzącej odpowiedzi nadano wartość 1, a przeczącej 0 . Następnie zsumowano te wartości - każdy respondent mógł otrzymać od 0 do 4 punktów. Współczynnik $\alpha$-Cronbacha przyjął wysokie wartości: dla skali strategii zachowań pasywnych 0,88 i 0,83 dla zachowań aktywnych.
} 
tylko płeć i miejsce zamieszkania. Szczególnie często tego typu zachowania były wykazywane przez kobiety i mieszkańców obu części Centrum.

Bardzo rzadko respondenci deklarowali unikanie samotnego wychodzenia $z$ domu po zmroku. W tym przypadku analiza nie jest jednoznaczna, gdyż niektóre osoby w trakcie przeprowadzania wywiadów mówiły, że po prostu nie mają takiej potrzeby. W takich przypadkach niewychodzenie z domu nie może być interpretowane w kategoriach reakcji, bądź jej braku na sytuację zagrożenia. Otrzymane opinie respondentów potwierdzają raczej opisywane w literaturze zjawisko, jakim jest ogólnie niska skłonność Polaków do wychodzenia z domu i wykazywania różnych zachowań wieczorem poza domem. Dotyczy to zarówno niskiego poziomu uczestnictwa w wydarzeniach kulturalnych i rozrywkowych, ale także zwykłych spotkań towarzyskich w restauracjach czy pubach.

Właściwie jedynym aktywnym zachowaniem obronnym często wyrażanym przez respondentów było instalowanie dodatkowych zabezpieczeń domu/mieszkania przed włamaniem. Tak deklarowała ponad połowa respondentów. W przypadku tego technicznego środka zabezpieczeń, to mężczyźni (55\%) częściej niż kobiety deklarowali ich stosowanie. Częstotliwość ich stosowania wzrasta również wraz z wykształceniem respondenta $(43 \%$ osób z wykształceniem podstawowym i zawodowym, wobec $66 \% \mathrm{z}$ wykształceniem wyższym i niepełnym wyższym). Ponadto do zainstalowania dodatkowych zabezpieczeń przyznało się $57 \%$ respondentów w wieku 30-49 lat, a w dalszej kolejności - w wieku 50-59 lat (52\%) oraz powyżej lat 60 -ciu (51\%). To zachowanie obronne charakteryzuje głównie mieszkańców Radiostacji, Dołów i Karolewa, respondenci z Centrum stosują opisywane zabezpieczenia rzadziej niż przeciętna częstość wśród ogółu badanych. Zdaniem autora, dodatkowe zabezpieczanie mieszkań przez tylko około połowę respondentów to bardzo niski wskaźnik, zważywszy na niski standard powszechnie stosowanych podstawowych zabezpieczeń w blokach spółdzielczych i domach komunalnych. Okazuje się, że tak dużo osób wierzy w skuteczność standardowych zabezpieczeń i nie jest zainteresowana poprawą swojego bezpieczeństwa tymi środkami.

Podsumowując, respondenci w celu zwiększenia swojego poczucia bezpieczeństwa i zapobieżenia ewentualnym zagrożeniom zdecydowanie częściej podejmowali pasywne strategie zachowań obronnych (rys. 4). Warte podkreślenia jest, że aż 37\% badanych osób nie podjęło żadnego z przedstawionych zachowań aktywnych, podczas gdy w przypadku zachowań pasywnych było to tylko $10 \%$. Ponadto tylko 11 (czyli 1\%) osób potwierdziło stosowanie wszystkich czterech strategii zachowań aktywnych, wobec $17 \%$ badanych stosujących wszystkie wymienione w kwestionariuszu zachowania pasywne.

Postanowiono także sprawdzić, na ile stosowane strategie zachowań obronnych zależą od subiektywnego poczucia zagrożenia i miejsca zamieszkania respondentów (tab. 3). 

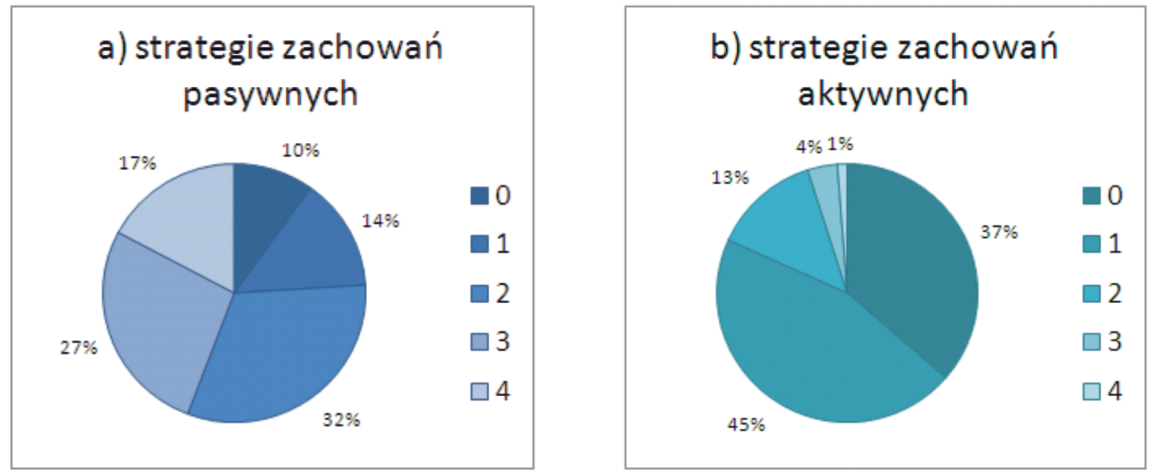

Rys. 4. Liczba podejmowanych przez respondentów strategii zachowań obronnych (od 0 do 4)

Źródło: opracowanie własne

Tabela 3

Poczucie zagrożenia według płci, wieku i wykształcenia respondentów

\begin{tabular}{|c|l|c|c|}
\hline \multirow{2}{*}{ Wyszczególnienie } & \multicolumn{2}{c|}{$\begin{array}{c}\text { Liczba podejmowanych } \\
\text { strategii zachowań }\end{array}$} \\
\cline { 2 - 4 } & $\begin{array}{c}\text { Zachowania } \\
\text { pasywne }\end{array}$ & $\begin{array}{c}\text { Zachowania } \\
\text { aktywne }\end{array}$ \\
\hline \multirow{4}{*}{ Ogółem } & 2,28 & 0,94 \\
\hline \multirow{4}{*}{$\begin{array}{c}\text { Subiektywne po- } \\
\text { czucie zagrożenia }\end{array}$} & Brak & 1,64 & 0,67 \\
\cline { 2 - 4 } & Niskie & 1,76 & 0,61 \\
\cline { 2 - 4 } & Srednie & 2,44 & 1,08 \\
\cline { 2 - 4 } & Wysokie & 3,11 & 1,27 \\
\hline \multirow{4}{*}{ Osiedle SIM } & Centrum-Północ & 2,63 & 0,79 \\
\cline { 2 - 4 } & Centrum-Południe & 2,39 & 0,84 \\
\cline { 2 - 4 } & Doły & 2,11 & 0,96 \\
\cline { 2 - 4 } & Karolew & 2,17 & 0,98 \\
\cline { 2 - 4 } & Radiostacja & 2,01 & 1,20 \\
\hline
\end{tabular}

Źródło: zestawienie własne.

Na zachowania obronne istotny wpływ ma subiektywne poczucie zagrożenia. Osoby o wysokim poczuciu zagrożenia przejawiają najwięcej zachowań obronnych - zarówno tych pasywnych, jak i aktywnych. W kwestii tej relacji uzyskany obraz jest zaskakująco jasny: im niższe jest subiektywne poczucie zagrożenia, czyli większe poczucie bezpieczeństwa, tym mniej zachowań obronnych badane osoby wykazują. Oby tylko, paradoksalnie, wysokie poczucie bezpieczeństwa 
i rzadko stosowane zachowania obronne, nie uśpiły nadto czujności tych osób, bo wówczas łatwo mogłyby stać się ofiarą któregoś z lokalnych zagrożeń.

Mieszkańcy poszczególnych badanych osiedli stosują od 3,07 do 3,42 różnych zachowań obronnych. Większa liczba tych zachowań charakterystyczna jest dla osób mieszkających w obu częściach Centrum - północnej i południowej. W przypadku tych respondentów stwierdzono większą niż przeciętnie w całej populacji skłonność do wyboru pasywnych strategii obronnych. Podobną jak wśród mieszkańców Centrum-Południa liczbę strategii zachowań podejmują osoby z Radiostacji, tyle tylko, że oni mają większe upodobanie do zachowań aktywnych.

\section{Podsumowanie}

O poczuciu zagrożenia mieszkańców danego obszaru decyduje złożony układ stosunków społeczno-przestrzennych. Podejmując ten projekt bazowano na wynikach badań przeprowadzonych w latach 2011-2012. Określono wówczas znaczenie wpływu zagospodarowania przestrzeni na stopień dysproporcji różnych problemów o charakterze społeczno-przestrzennym. W tym projekcie postanowiono sprawdzić, czy występujące w badanych przestrzeniach różne natężenie problemów społecznych przekłada się w jakiś sposób na poziom subiektywnego poczucia zagrożenia mieszkańców i jakie w związku z tym wykazują oni strategie zachowań obronnych.

W toku przeprowadzonych analiz udało się potwierdzić słuszność postawionej hipotezy o zróżnicowaniu postaw związanych z zachowaniami obronnymi mieszkańców miasta, będących reakcją na dysproporcje przestrzenne różnorodnych zagrożeń i patologii społeczno-przestrzennych. W artykule w wielu miejscach podkreślano istotność znaczenia miejsca zamieszkania w wyrażanych opiniach i podejmowanych przez respondentów zachowaniach obronnych.

W porównaniu z opracowaniami dotyczącymi poczucia bezpieczeństwa mieszkańców różnych miast, łodzianie charakteryzują się generalnie wyższym poczuciem zagrożenia, a przy tym stosują mniej różnych strategii zachowań obronnych. Cóż, tak jak samo poczucie zagrożenia jest w swojej istocie w znacznym stopniu irracjonalne (nie jest prostą funkcją znanych - dających się określić czynników), tak samo trudne do przewidzenia mogą być zachowania mieszkańców miasta. Tym niemniej, w prezentowanych tutaj badaniach stwierdzono istotny i pozytywny związek między subiektywnym poczuciem zagrożenia i liczbą podejmowanych strategii obronnych. Stwierdzić można zatem, że poczucie zagrożenia jest konsekwencją występujących problemów w danym środowisku społeczno-przestrzennym, co z kolei wpływa na zachowania mieszkańców. 


\section{LITERATURA}

Bauman Z., 2004, Życie na przemiat, Wydawnictwo Literackie, Kraków.

Breckler S.J., 1984, Empirical validation of affect, behaviour and cognition as distinct components of attitude, ,Journal of Personality and Social Psychology”, 47, s. 11911205.

Czekaj K., 1991, Mapy problemów społecznych jako narzędzie badawcze ekologii humanistycznej. Aspekty teoretyczne i empiryczne, [w:] Wódz J. (red.), Zagrożenia ekologiczne, warunki życia, wizje przyszłości, Wydawnictwo Śląsk, Katowice, s. 59-113.

Dzieciuchowicz J., 2011, Środowisko mieszkaniowe wielkiego miasta. Przykład Łodzi, Wydawnictwo UŁ, Łódź.

Grotowska-Leder J., 2001, Przestrzeń miejska a zjawiska upośledzenia społecznego (na przykładzie Łodzi), [w:] Rogacki H. (red.), Koncepcje teoretyczne i metody badań geografii społeczno-ekonomicznej i gospodarki przestrzennej, Bogucki Wydawnictwo Naukowe, Poznań, s. 215-227.

Jasiński A., 2009, Wielkomiejski dylemat - przestrzeń publiczna czy przestrzeń bezpieczna, „Przestrzeń i Forma”, 12, s. 319-351.

Jerschina J., Lesińska E., Pytliński Ł., Siwek H., 2012, Badania poczucia bezpieczeństwa mieszkańców Prądnika Czerwonego w Krakowie ze szczególnym uwzględnieniem wplywu zmian architektonicznych i technicznych na poziom lęku przed przestępczościa, [w:] Czapska J. (red.), Zapobieganie przestępczości przez kształtowanie przestrze$n i$, Wydawnictwo UJ, Kraków.

Kotus J., 2005, Społeczne dylematy w przestrzeni miejskiej, Bogacki Wydawnictwo Naukowe, Poznań.

Mordwa S., 2003, Wyobrażenia przestrzeni miast Polski Środkowej. Na podstawie badań grupy młodzieży licealnej, Wydawnictwo UŁ, Łódź.

Mordwa S., 2010, Poczucie bezpieczeństwa mieszkańców wybranych osiedli w Łodzi, [w:] Madurowicz M. (red.), Wartościowanie współczesnej przestrzeni miejskiej, WGSR UW, Warszawa.

Mordwa S., 2011, Poczucie bezpieczeństwa w Łodzi. Przykład badań mieszkańców osiedli mieszkaniowych, „Space-Society-Economy”, 10, s. 181-196.

Mordwa S., 2012, Poczucie bezpieczeństwa w centrach handlowych. Przykład badań opinii klientów Galerii Łódzkiej i Manufaktury w Lodzi, „Acta Universitatis Lodziensis. Folia Geographica Socio-Oeconomica", 12, s. 163-187.

Mordwa S., 2013, Przestępczość i poczucie bezpieczeństwa w przestrzeni miasta. Przykład Łodzi, Wydawnictwo UŁ, Łódź.

Mordwa S., 2014, Dysproporcje przestrzenne wybranych zjawisk patologii spolecznych w Lodzi, [w:] Suliborski A., Wójcik M. (red.), Dysproporcje spoleczne i gospodarcze w przestrzeni Łodzi. Czynniki, mechanizmy, skutki, Wydawnictwo UŁ, Łódź, s. 277-303.

Prawelska-Skrzypek G., Porębski W., 2003, Obszary deprywacji w Krakowie oraz zmiany w ich rozmieszczeniu w latach 1992-2001, „Nierówności Społeczne a Wzrost Gospodarczy", 2, s. 433-445.

Sillamy N., 1989, Słownik psychologiczny, Wydawnictwo Książnica, Warszawa.

Suliborski A., Wójcik M. (red.), 2014, Dysproporcje społeczne i gospodarcze w przestrzeni Łodzi. Czynniki, mechanizmy, skutki, Wydawnictwo UŁ, Łódź. 
Wallis A., 1971, Socjologia i kształtowanie przestrzeni, PIW, Warszawa.

Warzywoda-Kruszyńska W. (red.), 2001, (Żyć) Na marginesie wielkiego miasta, Absolwent, Łódź.

Weltrowska J., Kisiała W., 2014, Obszary koncentracji ubóstwa w strukturze przestrzennej miasta, Prace Naukowe Uniwersytetu Ekonomicznego we Wrocławiu, 331, s. 235-245.

Węcławowicz G., 2001, Przestrzeń ubóstwa - nowy czy stary wymiar zróżnicowania społeczno-przestrzennego w miastach Polski, „Przegląd Geograficzny”, 73(4), s. 451-475.

Wolaniuk A., 2012, Centra miast, [w:] Liszewski S. (red.), Geografia urbanistyczna, PWN, Warszawa.

Zborowski A., 2010, Społeczny aspekt rewitalizacji, [w:] Ziobrowski Z., Jarczewski W. (red.), Rewitalizacja miast polskich - diagnoza, Instytut Rozwoju Miast, Kraków, s. $65-81$.

\title{
THE SUBJECTIVE SENSE OF THREAT AND DEFENSIVE BEHAVIOURS OF THE RESIDENTS OF ŁÓDŹ
}

\begin{abstract}
The issues of safety and security in modern cities are complicated and economic, social, cultural, political and spatial dimensions become very important. In this paper the socio-spatial factors affecting residents' sense of threat and behaviour were studying. The question of "what are the most important socio-spatial factors that can affect the sense of security in cities?" was answered. The research population consisted of the residents of five different areas of the city of Łódź who were 18 years old and above of which a sample of 900 individuals were chosen. These findings showed that perceived socio-spatial threats could strongly affect the residents' defensive behaviours.
\end{abstract}

Key words: defensive behaviour, sense of security, socio-spatial threats, Łódź.

Dr hab. Stanisław Mordwa, prof. UŁ Katedra Zagospodarowania Środowiska i Polityki Przestrzennej Wydział Nauk Geograficznych, Uniwersytet Łódzki 